\title{
Effect of Stem Rust on the Quality of Selected Barley Genotypes
}

\author{
K. E. Mwando, ${ }^{1}$ I. M. Tabu, ${ }^{1}$ O. D. Otaye, ${ }^{2}$ and P. N. Njau ${ }^{3}$ \\ ${ }^{1}$ Department of Crops Horticulture and Soils, Egerton University, P.O. Box 536, Egerton, Kenya \\ ${ }^{2}$ Department of Biological Sciences, Egerton University, P.O. Box 536, Egerton, Kenya \\ ${ }^{3}$ National Plant Breeding Centre, Kenya Agricultural Research Institute, P.O. Box Private Bag, Njoro, Kenya \\ Correspondence should be addressed to K. E. Mwando, edwardmwando@gmail.com
}

Received 1 December 2011; Accepted 11 January 2012

Academic Editor: I. Vasilakoglou

Copyright ( 2012 K. E. Mwando et al. This is an open access article distributed under the Creative Commons Attribution License, which permits unrestricted use, distribution, and reproduction in any medium, provided the original work is properly cited.

Stem rust, (Puccinia graminis f.sp. tritici) is a catastrophic disease of barley. Previously stem-rust-tolerant genes were incorporated in genotypes of wheat grown in Kenya, but in 1999, a new race Ug99 that is virulent to the genes was detected in Uganda. The new race spread rapidly and, in 2001, stem rust Ug99 isolates were detected in Kenya. Although barley is an important crop affected by stem rust, limited work has been done to it. In this study 20 barley cultivars from Kenya and from International Centre for Agriculture Research in Dry Area (ICARDA) were screened in greenhouse environment and in the field with isolate of Puccinia graminis f.sp. tritici. At seedling stage, the infection levels ranged from 0 to 2, except in ICARDA-09 and ICARDA-11 that showed infection types 3 and 3, 4, respectively. At adult plant stage, genotypes ICARDA-01, Nguzo, and Karne were moderately resistant while the rest were susceptible or moderately susceptible. In the field, the new line 1512-5 showed the highest severity of 93\% in season 1, with Sabini having the highest severity of $30 \%$ in the second season. The highest reduction in percent germination $(54.1 \%$ and $38.3 \%$ ) was recorded in 1385-13 and ICARDA-10 in season 1 and 2, respectively. The highest loss (9.00\%) in protein content was observed in Sabini in season 1. It is evident that stem rust Ug99 is a threat to beer industry and there is need for regular monitoring of the stem rust pathogen, in particular isolates in the variable Ug99 lineage, as well as continued resistance breeding. The study has demonstrated the pathogenicity of PgtUg99 to barley despite the fact that it poses a great threat to wheat production in the world.

\section{Introduction}

Barley (Hordeum vulgare L.) is one of the most important cereal crops, in Kenya. Currently about 30,000 ha of land is under the crop but potential for expansion remains [1]. It is a principal raw material used to process malt, a vital ingredient for beer brewing. The industry is one of the highest corporate taxpayers with annual turnover of Kshs. 28.9 billion and employs more than 1600 people across the region [1]. Diseases however reduce the quality of barley resulting in lower returns to the grower [2,3]. Rust fungi, responsible for diseases like stem rust, yellow rust, and leaf rust are major contributors to the suboptimal yields realized by farmers. Breeding for tolerance has been used as the main method of protection against the fungi. The rust fungi can however overcome host tolerance genes and spread new strains through wind dispersal of spores [4]. Stem rust of barley and wheat (caused by Puccinia graminis f.sp. tritici, Eriks., and E. Henn.) is historically one of the most important plant diseases. Devastating stem rust epidemics often result in major grain losses [5] that contribute to about $\$ 5$ billion loss annually [6]. The problem of wheat stem rust was previously contained through the use of genetic resistance resulting from genes such as Sr31 [7]. In 1999 and 2001 a new race Ug99 or TTKS with virulence to stem rust tolerant cultivars was detected in Uganda and Kenya, respectively [8, 9]. Preliminary work indicates that race TTKS is virulent on Midwestern barley cultivars carrying the durable stem rust tolerance gene Rpg1 [10]. Stem rust race Ug99 is responsible for up to $100 \%$ yield loss of wheat. The race also affects barley where control using fungicides has been unsuccessful. Much of the work including genetic manipulation of wheat to control the disease has had little success. Barley is another crop that is affected by the Ug99 race; however, little work has been done to screen the barley genotypes for resistance to the new race of stem rust. This study was carried out to find out the level of tolerance in selected barley genotypes from Kenya and ICARDA to the new race of stem rust Ug99. 
TABLE 1: Type and source of barley germplasm used in the experiment.

\begin{tabular}{|c|c|c|}
\hline Genotypes code/name & Selection history & Source \\
\hline ICARDA-01 & CBSS99MOO39IT-H-IM-IY-IM-IY-OM & ICARDA \\
\hline ICARDA-02 & CBSS99MOO317T-AH-2M-IY-IM-IY-OM & ICARDA \\
\hline ICARDA-03 & CBSS00YOO113T-A-OY-OM-2Y-OM & ICARDA \\
\hline ICARDA-04 & CBSS99MOO429T-L-IM-IY-OM & ICARDA \\
\hline ICARDA-05 & CBSW99WMOOO95T-B-IM-IY-IM-OM & ICARDA \\
\hline ICARDA-06 & CBSS00YOOO48S-OY-OM-2Y-OM & ICARDA \\
\hline ICARDA-07 & CBSSOOYOO475T-O-OY-OM-2Y-OM & ICARDA \\
\hline ICARDA-08 & CBSSOOYOO236T-E-0Y-OM-2Y-OM & ICARDA \\
\hline ICARDA-09 & CBSS99MOO349T-F-3M-IY-IM-OM & ICARDA \\
\hline ICARDA-10 & CBSS99MOO468T-H-IM-IY-OM & ICARDA \\
\hline ICARDA-11 & CBSSOOYOO479T-D-OY-OM-IM-OM & ICARDA \\
\hline ICARDA-12 & CBSW98WOOO54S-BY-2M-IY-2M-IY-OM & ICARDA \\
\hline ICARDA-13 & CBSS99MOO315T-F-IM-F-IM-IY-IM-IY-OM & ICARDA \\
\hline ICARDA-14 & CBSSOOYOO225T-C-OY-OM-2Y-IM-OM & ICARDA \\
\hline ICARDA-15 & CBSSOOYOO278D-G-OY-OM-2Y-OM & ICARDA \\
\hline $1385-13$ & - & KENYA \\
\hline NGUZO & - & KENYA \\
\hline $1512-5$ & - & KENYA \\
\hline KARNE & - & KENYA \\
\hline SABINI & - & KENYA \\
\hline
\end{tabular}

\section{Materials and Methods}

The experiment was carried out at the Kenya Agricultural Research Institute (KARI)—Njoro situated along the NjoroMau Narok road in Nakuru County, located at $0^{\circ} 20^{\prime} \mathrm{S}$ $35^{\circ} 56^{\prime} \mathrm{E}$ and at 2185 meters above sea level. Twenty barley germplasms that included three Kenyan commercial cultivars (Nguzo, Sabini, and Karne), two (1512-5 and 1385-13) new introductions from the Kenya malting company, and 15 selections from ICARDA were used (Table 1).

2.1. Stem Rust Isolate Preparation. The spores used for inoculation were collected from experimental plots in KARINjoro. The stem rust spore (urediniospore) samples consisted of bulk isolate collected using a portable powered suction pump (Hoover Model, 2944B) from wheat cultivar Chozi. The inoculum was pretested on differential hosts in the greenhouse according to Roelfs and Martens [11] and confirmed to be those of PgtUg99. To generate large quantities of urediniospores, the isolate was inoculated onto seedlings of the susceptible wheat cultivar Chozi having gene Sr31. The Urediniospores were suspended in distilled water where light mineral of oil (tween 20 solution) was added and the suspension sprayed onto the plants using a small bowleratomizer. The plants were then kept in a dark humidity chamber overnight before taking them to clear plastic chambers in the greenhouse to prevent contamination resulting from the movement of urediniospores. Urediniospores were harvested from sporulating pustules at 14 and 21 days after inoculation using a cyclone spore collector. The spores were then dried for 2 to 3 days over silica gel in the laboratory.
2.2. The Infection Type at Seedling Stage. The greenhouse experiment was arranged in a completely randomized design (CRD) with three replicates done by sowing the 20 barley germplasms in $15 \mathrm{~cm}$ plastic pots filled with forest soil that had been autoclaved at $121^{\circ} \mathrm{C}$ and 15 -pound pressure for one hour [12]. The urediniospore suspension (1 mg of urediniospore per $100 \mathrm{~mL}$ of distilled water) was mixed with 4 drops of tween 20, surfactant using a small bowler-atomizer and inoculated on the seedlings. The inoculation involved uniform spraying of the upper and lower leaf surfaces of individual plants 10 days after germination. Immediately after inoculation the seedlings were incubated for 24 hours in a dark dew chamber kept moist by frequently spraying with water to maintain humidity of $80-100 \%$ and temperatures between $16^{\circ} \mathrm{C}$ and $22^{\circ} \mathrm{C}$. The seedlings were transferred to the greenhouse after incubation. For the first two hours, the leaves were sprayed with water for 15 minutes at an interval of 30 minutes using an atomizer. Temperature of $22-30^{\circ} \mathrm{C}$ was thereafter maintained in the green house, following the procedure by McIntosh et al. [13]. Fourteen days after inoculation the seedlings were assessed for disease severity according to Stakman et al. [14] scale for stem rust where 0 : Immune, ;: very resistant, 1 : resistant, 2 : moderately resistant, 3: moderately susceptible and 4: susceptible.

2.3. The Reaction Type to Stem Rust at Adult Plant Stage. Twenty barley germplasm were sown in $20 \mathrm{~cm}$ diameter plastic plots filled with sterile forest soil. Diammonium phosphate $\left(18 \% \mathrm{~N}\right.$ and $\left.46 \% \mathrm{P}_{2} \mathrm{O}_{5}\right)$ at the rate of $50 \mathrm{Kg} / \mathrm{ha}$ that translates to $125 \mathrm{mg}$ per pot was thoroughly mixed with the soil where 10 seeds of each cultivar were sown in one pot. 
TABLE 2: Seedling infection type and adult plant reaction of barley to PgtUg99 in the greenhouse.

\begin{tabular}{|c|c|c|c|}
\hline Genotypes code/name & Selection history & Seedling infection type $\mathrm{e}^{\mathrm{a}}$ & Adult plant reaction ${ }^{\mathrm{b}}$ \\
\hline ICARDA-01 & CBSS99MOO39IT-H-IM-IY-IM-IY-OM & ; & MR \\
\hline ICARDA-02 & CBSS99MOO317T-AH-2M-IY-IM-IY-OM & 0 & $S$ \\
\hline ICARDA-03 & CBSS00YOO113T-A-OY-OM-2Y-OM & 0 & S \\
\hline ICARDA-04 & CBSS99MOO429T-L-IM-IY-OM & 0 & S-MS \\
\hline ICARDA-05 & CBSW99WMOOO95T-B-IM-IY-IM-OM & 1 & S \\
\hline ICARDA-06 & CBSS00YOOO48S-OY-OM-2Y-OM & 1 & MS \\
\hline ICARDA-07 & CBSSOOYOO475T-O-OY-OM-2Y-OM & 1 & MS-S \\
\hline ICARDA-08 & CBSSOOYOO236T-E-0Y-OM-2Y-OM & 1 & S \\
\hline ICARDA-09 & CBSS99MOO349T-F-3M-IY-IM-OM & 3 & S \\
\hline ICARDA-10 & CBSS99MOO468T-H-IM-IY-OM & 0 & S-MS \\
\hline ICARDA-11 & CBSSOOYOO479T-D-OY-OM-IM-OM & $; 1$ & S \\
\hline ICARDA-12 & CBSW98WOOO54S-BY-2M-IY-2M-IY-OM & 4,3 & S \\
\hline ICARDA-13 & CBSS99MOO315T-F-IM-F-IM-IY-IM-IY-OM & $; 0$ & S \\
\hline ICARDA-14 & CBSSOOYOO225T-C-OY-OM-2Y-IM-OM & 2 & MR \\
\hline ICARDA-15 & CBSSOOYOO278D-G-OY-OM-2Y-OM & 2 & S \\
\hline $1385-13$ & - & 1 & S \\
\hline NGUZO & - & 0 & R-MR \\
\hline $1512-5$ & - & 0,2 & $S$ \\
\hline KARNE & - & 2 & MS-MR \\
\hline SABINI & - & 1 & S \\
\hline
\end{tabular}

Two weeks after emergence plants were thinned to eight. The pots were placed on trays with gravel and watering done every other day for 30 minutes. At flag leaf stage plants were inoculated with urediniospores suspension ( $1 \mathrm{mg}$ urediniospores $/ 100 \mathrm{~mL}$ of distilled water plus 5 drops of tween 20 surfactant) using a syringe and a hypodermic needle. The urediniospore suspension was injected into elongating stems, where each plant received $0.5 \mathrm{~mL}$ of the suspension [12], and then in a dark dew chamber over night. The plants were then moved to the greenhouse and placed on a bench where a spray of water was applied on the leaves every 15 minutes for 2 hours to maintain temperature between 22 and $30^{\circ} \mathrm{C}$. The experiment was laid out as a completely randomized design (CRD) with three replicates. The disease reaction was rated based on the size of the pustules and associated necrosis or chlorosis 14 days after inoculation and weekly thereafter as described by Roelfs et al. [15] where R: resistant; MR: moderately resistant; MS: moderately susceptible, and S: susceptible.

2.4. Stem Rust Severity and Infection Type in Field. Twenty barley cultivars were screened for their level of tolerance to stem rust disease in the field and evaluated for the losses in quality associated with stem rust Ug99. The experiments were planted for two seasons at KARI Njoro during the
2008/2009 crop seasons at Kenya Agricultural Research Institute (KARI), Njoro, situated along the Njoro-Mau Narok road in Nakuru County, located at $0^{\circ} 20^{\prime} \mathrm{S} 35^{\circ} 56^{\prime} \mathrm{E}$ and at 2185 meters above sea level. It receives an average rainfall of $939 \mathrm{~mm}$ per annum, with a mean temperature range of $9.5^{\circ} \mathrm{C}$ to $24^{\circ} \mathrm{C}$ and falls within the agroecological zone III [16]. The soils are predominantly Mollic Andosols. The site represents the best condition for the development of stem rust disease hence it is described as a hot spot for stem rust and most of the screening work is done in the station. The cultivars were sown in plots of $3 \mathrm{~m}$ length at spacing of $20 \mathrm{~cm}$, at seed rate of $125 \mathrm{~kg} / \mathrm{ha}$. The same set was sown as control under fungicides application of tebuconazole (folicur) at 0.75l/ha, 3 times in the season starting at stem elongation stage [17] at an interval of 21 days. The experimental design was randomized complete block design (RCBD) in split plot arrangement with the main plots as the 20 barley cultivars while the subplots consisted of fungicide (protected and unprotected), replicated three times. Susceptible wheat cultivar, Chozi, was planted perpendicular to test plots in the middle of the $1 \mathrm{~m}$ pathways on both sides of experimental plots to serve as spreader. All the agronomic practices were done according to the recommendations. The spreader rows were inoculated with $P . g$. tritici pathotype TTKSK at the early jointing stage by injecting an aqueous suspension of urediniospores into the hollow culm of plants at $0.75 \mathrm{~m}$ intervals along each 
TABle 3: Adult plant response to infection and disease severity (\%) of barley germplasm to PgtUg99 in the field.

\begin{tabular}{|c|c|c|c|c|}
\hline Genotypes code/name & Selection history & Season 1 & Season 2 & Mean \% \\
\hline ICARDA-01 & CBSS99MOO39IT-H-IM-IY-IM-IY-OM & $23 * \mathrm{MR}^{* *}$ & $7 \mathrm{MR}$ & 15 \\
\hline ICARDA-02 & CBSS99MOO317T-AH-2M-IY-IM-IY-OM & $28 \mathrm{~S}$ & $6 \mathrm{~S}$ & 17 \\
\hline ICARDA-03 & CBSS00YOO113T-A-OY-OM-2Y-OM & $56 \mathrm{~S}$ & $18 \mathrm{~S}$ & 37 \\
\hline ICARDA-04 & CBSS99MOO429T-L-IM-IY-OM & 46S-MS & $13 \mathrm{MS}$ & 30 \\
\hline ICARDA-05 & CBSW99WMOOO95T-B-IM-IY-IM-OM & $41 \mathrm{~S}$ & $13 \mathrm{~S}$ & 27 \\
\hline ICARDA-06 & CBSS00YOOO48S-OY-OM-2Y-OM & $23 \mathrm{MS}$ & $9 \mathrm{MS}$ & 16 \\
\hline ICARDA-07 & CBSSOOYOO475T-O-OY-OM-2Y-OM & 40MS-S & $16 \mathrm{MS}$ & 28 \\
\hline ICARDA-08 & CBSSOOYOO236T-E-0Y-OM-2Y-OM & $45 S$ & $16 \mathrm{MS}$ & 31 \\
\hline ICARDA-09 & CBSS99MOO349T-F-3M-IY-IM-OM & $53 \mathrm{~S}$ & $15 S$ & 34 \\
\hline ICARDA-10 & CBSS99MOO468T-H-IM-IY-OM & $46 \mathrm{MS}$ & $15 \mathrm{MS}$ & 31 \\
\hline ICARDA-11 & CBSSOOYOO479T-D-OY-OM-IM-OM & $73 S$ & $13 S$ & 43 \\
\hline ICARDA-12 & CBSW98WOOO54S-BY-2M-IY-2M-IY-OM & $50 \mathrm{~S}$ & $15 S$ & 33 \\
\hline ICARDA-13 & CBSS99MOO315T-F-IM-F-IM-IY-IM-IY-OM & $63 S$ & $21 S$ & 42 \\
\hline ICARDA-14 & CBSSOOYOO225T-C-OY-OM-2Y-IM-OM & 20MS & $6 \mathrm{MS}$ & 13 \\
\hline ICARDA-15 & CBSSOOYOO278D-G-OY-OM-2Y-OM & $36 \mathrm{~S}$ & $16 S$ & 26 \\
\hline $1385-13$ & - & $86 \mathrm{~S}$ & $16 S$ & 51 \\
\hline NGUZO & - & 16R-MR & $5 \mathrm{MR}$ & 11 \\
\hline $1512-5$ & - & $93 \mathrm{~S}$ & $21 S$ & 57 \\
\hline KARNE & - & 46R-MR & $13 \mathrm{MR}$ & 30 \\
\hline SABINI & - & $63 \mathrm{~S}$ & $3 \mathrm{OS}$ & 47 \\
\hline
\end{tabular}

* Disease severity scale from 0 to $100 \%$, as based on Peterson et al. [18].

** Infection type responses based on Roelfs et al. [15], McIntosh et al. [13].

spreader. The infection type responses as described by Roelfs et al. [15], McIntosh et al. [13] and disease severities 0$100 \%$ by Peterson et al. [18] were recorded in both trials starting from when $50 \%$ of the plants reached heading stage at an interval of 14 days until hardening stage. Germination percentage was determined on the barley harvested from the treated and untreated plots as described by ASBC Barley 3C, IOB, and EBC procedure. An Infratec 1241 Grain Analyzer was used to determine protein, starch, Zeleny, and gluten content of the grains from the treated and untreated plots. The Infratec Grain Analyzer is a whole grain analyzer that has a wavelength range of 570-1100 $\mathrm{nm}$ to allow analysis of quality parameters such as protein, moisture, starch, oil, test weight, and colour with high accuracy.

\section{Results and Discussion}

3.1. Infection Levels of Stem Rust in the Greenhouse. The germplasms showed varying levels of tolerance to stem rust (Table 2). At seedling stage, the infection levels ranged from 0 to 2 , except in ICARDA-09 and ICARDA-11 that showed infection types 3 and 3,4, respectively. The tolerance at seedling stage may probably be because the germplasm had tolerance conferred by one single major gene that was broken down at adult plant stage. In adult plants reaction $60 \%$ of the population were susceptible, $20 \%$ moderately susceptible, $10 \%$ moderately susceptible to moderately resistant, and $10 \%$ moderately resistant. Genotypes ICARDA- 01 and ICARDA-14 were moderately resistant (MR) while Nguzo was resistant to moderately resistant (R-MR). Karne was however moderately resistant to moderately susceptible reaction (MR-MS). The genotypes that showed some resistance at adult stage may contain a major single gene that remained resistant at seedling and at adult plant stage or they may have minor genes that are working together to reduce the disease [15].

3.2. Stem Rust Severity under Field Conditions. Disease pressure was higher in season 1 compared to season 2 probably because of differences in relative humidity and temperature. Among the 20 genotypes that were evaluated for adult plant tolerance, genotypes ICARDA-01, Nguzo, and Karne were moderately resistant while the rest were susceptible or moderately susceptible (Table 3 ). Genotype 1512-5 showed the highest severity of $(93 \%)$ in season 1, while Sabini had the highest severity of $30 \%$ in the second season. Nguzo had the lowest disease severity of $16 \%$ and 5\% in season 1 and 2 , respectively. Jin et al. [19] similarly noted an interaction between host genotypes and rust pathotypes which they attributed to variation in environmental temperature. Fox and Harder [20] noted that terminal disease severities were a reliable indicator of resistance to stem rust in wheat and barley. Barley germplasms that showed the highest final disease percent were considered very susceptible.

3.3. Germination Percentage. Percentage germination percentage varied with genotype and treatment. High percent germination was observed in treated plots compared to 
TABLE 4: Effect of stem rust disease on germination percent (\%) of barley genotypes.

\begin{tabular}{|c|c|c|c|c|}
\hline Genotypes code/name & Selection history & $\begin{array}{l}\text { Season } 1 \\
\text { Mean \%loss }\end{array}$ & $\begin{array}{l}\text { Season } 2 \\
\text { Mean \%loss }\end{array}$ & Season difference \\
\hline ICARDA-01 & CBSS99MOO39IT-H-IM-IY-IM-IY-OM & $20.4 \pm 5.58^{c}$ & $19.6 \pm 7.18^{\text {abcde }}$ & NS \\
\hline ICARDA-02 & CBSS99MOO317T-AH-2M-IY-IM-IY-OM & $23.5 \pm 9.93^{c}$ & $19.1 \pm 8.32^{\mathrm{abcde}}$ & $* *$ \\
\hline ICARDA-03 & CBSS00YOO113T-A-OY-OM-2Y-OM & $17.6 \pm 3.80^{c}$ & $3.8 \pm 1.99^{\mathrm{e}}$ & $* *$ \\
\hline ICARDA-04 & CBSS99MOO429T-L-IM-IY-OM & $50.6 \pm 8.94^{\mathrm{ab}}$ & $33.1 \pm 7.70^{\mathrm{ab}}$ & $* *$ \\
\hline ICARDA-05 & CBSW99WMOOO95T-B-IM-IY-IM-OM & $21.1 \pm 4.07^{\mathrm{c}}$ & $15.9 \pm 6.91^{\text {bcde }}$ & NS \\
\hline ICARDA-06 & CBSS00YOOO48S-OY-OM-2Y-OM & $16.5 \pm 2.63^{c}$ & $7.5 \pm 4.61^{\mathrm{de}}$ & $* *$ \\
\hline ICARDA-07 & CBSSOOYOO475T-O-OY-OM-2Y-OM & $38.9 \pm 12.42^{\mathrm{abc}}$ & $16.1 \pm 1.10^{\text {bcde }}$ & $* *$ \\
\hline ICARDA-08 & CBSSOOYOO236T-E-0Y-OM-2Y-OM & $19.5 \pm 10.16^{\mathrm{c}}$ & $8.4 \pm 5.51^{\mathrm{de}}$ & $* *$ \\
\hline ICARDA-09 & CBSS99MOO349T-F-3M-IY-IM-OM & $25.4 \pm 8.17^{\mathrm{c}}$ & $10.6 \pm 6.40^{\text {cde }}$ & $* *$ \\
\hline ICARDA-10 & CBSS99MOO468T-H-IM-IY-OM & $35.7 \pm 13.48^{\mathrm{abc}}$ & $38.3 \pm 5.09^{\mathrm{a}}$ & NS \\
\hline ICARDA-11 & CBSSOOYOO479T-D-OY-OM-IM-OM & $23.8 \pm 7.88^{\mathrm{c}}$ & $8.7 \pm 3.13^{\mathrm{de}}$ & $* *$ \\
\hline ICARDA-12 & CBSW98WOOO54S-BY-2M-IY-2M-IY-OM & $15.6 \pm 8.08^{c}$ & $12.1 \pm 9.43^{\text {cde }}$ & $* *$ \\
\hline ICARDA-13 & CBSS99MOO315T-F-IM-F-IM-IY-IM-IY-OM & $19.5 \pm 7.92^{c}$ & $25.6 \pm 3.40^{\mathrm{abc}}$ & NS \\
\hline ICARDA-14 & CBSSOOYOO225T-C-OY-OM-2Y-IM-OM & $21.2 \pm 5.55^{\mathrm{c}}$ & $2.6 \pm 1.24^{\mathrm{e}}$ & $* *$ \\
\hline ICARDA-15 & CBSSOOYOO278D-G-OY-OM-2Y-OM & $29.5 \pm 11.16^{\mathrm{c}}$ & $2.7 \pm 2.64^{\mathrm{e}}$ & $* *$ \\
\hline $1385-13$ & - & $54.1 \pm 9.71^{\mathrm{a}}$ & $17.1 \pm 4.98^{\text {bcde }}$ & $* *$ \\
\hline NGUZO & - & $34.5 \pm 5.53^{\mathrm{abc}}$ & $17.1 \pm 4.72^{\text {bcde }}$ & $* *$ \\
\hline $1512-5$ & - & $24.9 \pm 7.29^{c}$ & $5.4 \pm 1.80^{\mathrm{e}}$ & $* *$ \\
\hline KARNE & - & $18.5 \pm 14.67^{c}$ & $28.8 \pm 18.49^{\mathrm{abc}}$ & $* *$ \\
\hline SABINI & - & $51.5 \pm 7.82^{\mathrm{ab} *}$ & $29.8 \pm 3.82^{\mathrm{abc}}$ & $* *$ \\
\hline
\end{tabular}

Any two means in a column whose S.E. values overlap are not different at $\alpha=0.05$ by DMRT. ${ }^{*}$ Means followed by the same letter in column are not significantly different at $(P \leq 0.05)$.

**NS means the genotype was significantly and not significantly different between season.

TABLE 5: Effect of stem rust Ug99 on starch content (\%) of barley grains.

\begin{tabular}{|c|c|c|c|c|}
\hline Genotypes code/name & Selection history & $\begin{array}{c}\text { Season } 1 \\
\text { Mean \%loss }\end{array}$ & $\begin{array}{c}\text { Season } 2 \\
\text { Mean \%loss }\end{array}$ & Season difference \\
\hline ICARDA-01 & CBSS99MOO39IT-H-IM-IY-IM-IY-OM & $0.4 \pm 0.32^{\mathrm{b}}$ & $0.4 \pm 0.05^{\mathrm{b}}$ & NS \\
\hline ICARDA-02 & CBSS99MOO317T-AH-2M-IY-IM-IY-OM & $0.8 \pm 0.21^{\mathrm{ab}}$ & $0.5 \pm 0.34^{\mathrm{b}}$ & $* *$ \\
\hline ICARDA-03 & CBSS00YOO113T-A-OY-OM-2Y-OM & $1.7 \pm 0.29^{\mathrm{ab}}$ & $1.7 \pm 0.44^{\mathrm{a}}$ & NS \\
\hline ICARDA-04 & CBSS99MOO429T-L-IM-IY-OM & $1.0 \pm 0.47^{\mathrm{ab}}$ & $1.0 \pm 0.83^{\mathrm{ab}}$ & NS \\
\hline ICARDA-05 & CBSW99WMOOO95T-B-IM-IY-IM-OM & $1.5 \pm 0.51^{\mathrm{ab}}$ & $1.5 \pm 0.38^{\mathrm{ab}}$ & NS \\
\hline ICARDA-06 & CBSS00YOOO48S-OY-OM-2Y-OM & $0.9 \pm 0.06^{\mathrm{ab}}$ & $0.6 \pm 0.46^{\mathrm{ab}}$ & NS \\
\hline ICARDA-07 & CBSSOOYOO475T-O-OY-OM-2Y-OM & $0.5 \pm 0.24^{\mathrm{b}}$ & $0.6 \pm 0.27^{\mathrm{ab}}$ & $* *$ \\
\hline ICARDA-08 & CBSSOOYOO236T-E-0Y-OM-2Y-OM & $0.4 \pm 0.45^{\mathrm{b}}$ & $0.7 \pm 0.19^{\mathrm{ab}}$ & NS \\
\hline ICARDA-09 & CBSS99MOO349T-F-3M-IY-IM-OM & $0.6 \pm 0.15^{\mathrm{b}}$ & $0.7 \pm 0.26^{\mathrm{ab}}$ & NS \\
\hline ICARDA-10 & CBSS99MOO468T-H-IM-IY-OM & $0.2 \pm 0.16^{\mathrm{b}}$ & $0.5 \pm 0.38^{\mathrm{ab}}$ & NS \\
\hline ICARDA-11 & CBSSOOYOO479T-D-OY-OM-IM-OM & $0.7 \pm 0.21^{\mathrm{ab}}$ & $0.7 \pm 0.42^{\mathrm{ab}}$ & NS \\
\hline ICARDA-12 & CBSW98WOOO54S-BY-2M-IY-2M-IY-OM & $0.8 \pm 0.36^{\mathrm{ab}}$ & $0.8 \pm 0.11^{\mathrm{ab}}$ & NS \\
\hline ICARDA-13 & CBSS99MOO315T-F-IM-F-IM-IY-IM-IY-OM & $0.8 \pm 0.21^{\mathrm{ab}}$ & $0.3 \pm 0.39^{\mathrm{b}}$ & $* *$ \\
\hline ICARDA-14 & CBSSOOYOO225T-C-OY-OM-2Y-IM-OM & $0.5 \pm 0.10^{\mathrm{b}}$ & $0.4 \pm 0.28^{\mathrm{b}}$ & NS \\
\hline ICARDA-15 & CBSSOOYOO278D-G-OY-OM-2Y-OM & $1.1 \pm 0.46^{\mathrm{ab}}$ & $1.1 \pm 0.24^{\mathrm{ab}}$ & NS \\
\hline $1385-13$ & - & $1.1 \pm 0.10^{\mathrm{ab}}$ & $1.0 \pm 0.35^{\mathrm{ab}}$ & NS \\
\hline NGUZO & - & $2.4 \pm 2.02^{\mathrm{a}}$ & $2.4 \pm 0.41^{\mathrm{a}}$ & NS \\
\hline $1512-5$ & - & $0.5 \pm 0.47^{\mathrm{b}}$ & $1.1 \pm 0.28^{\mathrm{ab}}$ & $* *$ \\
\hline KARNE & - & $0.8 \pm 0.41^{\mathrm{ab}}$ & $0.8 \pm 0.73^{\mathrm{ab}}$ & NS \\
\hline SABINI & - & $0.9 \pm 0.69^{\mathrm{ab}}$ & $0.9 \pm 0.51^{\mathrm{ab}}$ & NS \\
\hline
\end{tabular}

Any two means in a column whose S.E. values overlap are not different at $\alpha=0.05$ by DMRT. ${ }^{*}$ Means followed by the same letter in column are not significantly different at $(P \leq 0.05)$.

$* *$ NS means the genotype was significantly and not significantly different between season. 
TABLE 6: Effect of stem rust Ug99 on protein content (\%) of barley.

\begin{tabular}{|c|c|c|c|c|}
\hline Genotypes code/ Name & Selection history & $\begin{array}{c}\text { Season } 1 \\
\text { Mean \%loss }\end{array}$ & $\begin{array}{c}\text { Season } 2 \\
\text { Mean \%loss }\end{array}$ & Season difference \\
\hline ICARDA-01 & CBSS99MOO39IT-H-IM-IY-IM-IY-OM & $1.8 \pm 0.14^{\mathrm{b}}$ & $2.1 \pm 0.39^{\mathrm{a}}$ & NS \\
\hline ICARDA-02 & CBSS99MOO317T-AH-2M-IY-IM-IY-OM & $3.7 \pm 0.83^{\mathrm{ab}}$ & $2.9 \pm 0.50^{\mathrm{a}}$ & $* *$ \\
\hline ICARDA-03 & CBSS00YOO113T-A-OY-OM-2Y-OM & $6.0 \pm 3.10^{\mathrm{ab}}$ & $3.3 \pm 2.40^{\mathrm{a}}$ & $* *$ \\
\hline ICARDA-04 & CBSS99MOO429T-L-IM-IY-OM & $5.0 \pm 0.24^{\mathrm{ab}}$ & $7.1 \pm 3.09^{\mathrm{a}}$ & NS \\
\hline ICARDA-05 & CBSW99WMOOO95T-B-IM-IY-IM-OM & $3.6 \pm 2.10^{\mathrm{ab}}$ & $2.0 \pm 1.32^{\mathrm{a}}$ & $* *$ \\
\hline ICARDA-06 & CBSS00YOOO48S-OY-OM-2Y-OM & $5.4 \pm 0.91^{\mathrm{ab}}$ & $1.6 \pm 0.79^{\mathrm{a}}$ & $* *$ \\
\hline ICARDA-07 & CBSSOOYOO475T-O-OY-OM-2Y-OM & $4.7 \pm 3.65^{\mathrm{b}}$ & $4.8 \pm 1.10^{\mathrm{a}}$ & NS \\
\hline ICARDA-08 & CBSSOOYOO236T-E-0Y-OM-2Y-OM & $4.1 \pm 1.86^{\mathrm{ab}}$ & $3.9 \pm 2.12^{\mathrm{a}}$ & NS \\
\hline ICARDA-09 & CBSS99MOO349T-F-3M-IY-IM-OM & $0.8 \pm 0.72^{\mathrm{b}}$ & $3.4 \pm 1.24^{\mathrm{a}}$ & $* *$ \\
\hline ICARDA-10 & CBSS99MOO468T-H-IM-IY-OM & $4.1 \pm 1.10^{\mathrm{ab}}$ & $3.8 \pm 1.14^{\mathrm{a}}$ & $* *$ \\
\hline ICARDA-11 & CBSSOOYOO479T-D-OY-OM-IM-OM & $2.6 \pm 0.88^{\mathrm{ab}}$ & $4.3 \pm 2.41^{\mathrm{a}}$ & NS \\
\hline ICARDA-12 & CBSW98WOOO54S-BY-2M-IY-2M-IY-OM & $3.4 \pm 1.91^{\mathrm{ab}}$ & $3.6 \pm 3.32^{\mathrm{a}}$ & NS \\
\hline ICARDA-13 & CBSS99MOO315T-F-IM-F-IM-IY-IM-IY-OM & $0.8 \pm 0.45^{\mathrm{b}}$ & $4.2 \pm 0.77^{\mathrm{a}}$ & $* *$ \\
\hline ICARDA-14 & CBSSOOYOO225T-C-OY-OM-2Y-IM-OM & $2.1 \pm 0.67^{\mathrm{b}}$ & $4.7 \pm 2.97^{\mathrm{a}}$ & NS \\
\hline ICARDA-15 & CBSSOOYOO278D-G-OY-OM-2Y-OM & $4.0 \pm 2.40^{\mathrm{ab}}$ & $2.1 \pm 0.77^{\mathrm{a}}$ & NS \\
\hline $1385-13$ & - & $3.9 \pm 0.69^{\mathrm{ab}}$ & $2.2 \pm 1.47^{\mathrm{a}}$ & $* *$ \\
\hline NGUZO & - & $2.5 \pm 0.45^{\mathrm{b}}$ & $1.8 \pm 0.49^{\mathrm{a}}$ & $* *$ \\
\hline $1512-5$ & - & $4.5 \pm 1.50^{\mathrm{ab}}$ & $3.2 \pm 0.86^{\mathrm{a}}$ & $* *$ \\
\hline KARNE & - & $3.4 \pm 2.27^{\mathrm{ab}}$ & $3.2 \pm 2.86^{\mathrm{a}}$ & NS \\
\hline SABINI & - & $9.0 \pm 3.77^{\mathrm{a}}$ & $4.0 \pm 2.24^{\mathrm{a}}$ & $* *$ \\
\hline
\end{tabular}

*Any two means in a column whose S.E. values overlap are not different at $\alpha=0.05$ by DMRT. $*$ Means followed by the same letter in column are not significantly different at $(P \leq 0.05)$.

** NS means the genotype was significantly and not significantly different between seasons.

the untreated ones. The disease significantly affected the germination percent of barley. The highest reduction in percent germination (54.1\% and 38.3\%) was recorded in $1385-13$ and ICARDA-10 in season 1 and 2, respectively (Table 4). The reduction in germination percent could be attributed to low level of stored starch. Malting barley is one of the few grains where the seed is required to germinate for product development, that is, production of malt [21]. The failure of barley to germinate at an acceptable level (>95\%) could introduce problems during malting process. Benech-Arnold [22] noted that the most significant and relevant aspects of dormancy or preharvest sprouting are hormones and enzymes.

3.4. Starch Content. The stem rust Ug99 epidemics significantly reduced the starch content of barley (Table 5). Irrespective of season, the disease had the greatest effect on genotypes ICARDA-03, ICARDA-05, and Nguzo. Since the rust fungus is an obligate parasite, it derives the requirement from the host plant hence reducing the starch that can be stored. The ratio of carbon in respired $\mathrm{Co}_{2}$ contributed by $\mathrm{C}_{6}$ and $\mathrm{C}_{1}$ from hexose substrates (the $\mathrm{C}_{6}: \mathrm{C}_{1}$ ratio) declines from about 0.5 in healthy tissue to 0.3 at sporulation in rusted tissue [23]. The fungus utilizes available glucose, with reduced photosynthesis and increased respiration hence the total glucose available for storage as starch is reduced.
3.5. The Protein, Zeleny, and Gluten Content. Stem rust Ug99 significantly affected the protein and Zeleny content of barley. The highest loss (9.00\%) in protein content was observed in Sabini in season 1 (Table 6). A mean loss of 4.0 and $16.3 \%$ in Zeleny content was noted in season 1 and 2, respectively (Table 7). A mean of 17.1 and $53.2 \%$ in Nguzo was noted in season 1 and 2, respectively. Table 8 shows the effect of stem rust Ug99 on gluten content. Sabini and Nguzo gave gluten loss of 8.1 and $16.3 \%$ in season 1 and 2 , respectively. The fungus being an obligate parasite it utilizes the protein in the host for its structural growth and development. More frequently, the total protein of the host and parasite remains constant [24] or declines [25]. Much of the total protein can be assumed to be in the developing fungus, especially at sporulation and thereafter. Probably little protein is left in the host cell and subsequently little in the grain storage.

\section{Conclusion}

The study has demonstrated the pathogenicity of PgtUg99 to barley despite the fact that it poses a great threat to wheat production in the world. Most of the genotypes were resistant at seedling stage but were susceptible at the adult plant stage. Stem rust Ug99 epidemics despite causing a reduction in the total yield also has a great impact on 
TABLE 7: Effect of stem rust Ug99 on Zeleny content (\%) of barley.

\begin{tabular}{|c|c|c|c|c|}
\hline Genotypes code/name & Selection history & $\begin{array}{c}\text { Season } 1 \\
\text { Mean \%loss }\end{array}$ & $\begin{array}{c}\text { Season } 2 \\
\text { Mean \%loss }\end{array}$ & Season difference \\
\hline ICARDA-01 & CBSS99MOO39IT-H-IM-IY-IM-IY-OM & $3.8 \pm 0.73$ & $9.4 \pm 0.15^{\mathrm{abc}}$ & ** \\
\hline ICARDA-02 & CBSS99MOO317T-AH-2M-IY-IM-IY-OM & $2.2 \pm 1.66^{\mathrm{b}}$ & $6.5 \pm 2.06^{\mathrm{bc}}$ & $* *$ \\
\hline ICARDA-03 & CBSS00YOO113T-A-OY-OM-2Y-OM & $6.6 \pm 2.62^{\mathrm{ab}}$ & $19.4 \pm 4.82^{\mathrm{abc}}$ & $* *$ \\
\hline ICARDA-04 & CBSS99MOO429T-L-IM-IY-OM & $2.8 \pm 0.91^{\mathrm{b}}$ & $32.0 \pm 8.00^{\mathrm{ab}}$ & $* *$ \\
\hline ICARDA-05 & CBSW99WMOOO95T-B-IM-IY-IM-OM & $1.7 \pm 0.94^{\mathrm{b}}$ & $7.9 \pm 3.89^{\mathrm{abc}}$ & $* *$ \\
\hline ICARDA-06 & CBSS00YOOO48S-OY-OM-2Y-OM & $3.0 \pm 1.58^{\mathrm{b}}$ & $4.2 \pm 2.02^{\mathrm{c}}$ & $* *$ \\
\hline ICARDA-07 & CBSSOOYOO475T-O-OY-OM-2Y-OM & $1.7 \pm 1.35^{\mathrm{b}}$ & $16.4 \pm 1.00^{\mathrm{abc}}$ & $* *$ \\
\hline ICARDA-08 & CBSSOOYOO236T-E-0Y-OM-2Y-OM & $6.5 \pm 4.98^{\mathrm{ab}}$ & $9.8 \pm 3.03^{\mathrm{abc}}$ & NS \\
\hline ICARDA-09 & CBSS99MOO349T-F-3M-IY-IM-OM & $1.5 \pm 0.58^{\mathrm{b}}$ & $14.6 \pm 1.88^{\mathrm{abc}}$ & $* *$ \\
\hline ICARDA-10 & CBSS99MOO468T-H-IM-IY-OM & $2.7 \pm 0.27^{\mathrm{b}}$ & $4.8 \pm 1.73^{\mathrm{c}}$ & NS \\
\hline ICARDA-11 & CBSSOOYOO479T-D-OY-OM-IM-OM & $2.6 \pm 0.92^{\mathrm{b}}$ & $18.6 \pm 5.18^{\mathrm{abc}}$ & $* *$ \\
\hline ICARDA-12 & CBSW98WOOO54S-BY-2M-IY-2M-IY-OM & $4.3 \pm 1.28^{\mathrm{b}}$ & $6.4 \pm 3.18^{\mathrm{bc}}$ & NS \\
\hline ICARDA-13 & CBSS99MOO315T-F-IM-F-IM-IY-IM-IY-OM & $2.0 \pm 1.30^{\mathrm{b}}$ & $41.9 \pm 14.79^{a}$ & $* *$ \\
\hline ICARDA-14 & CBSSOOYOO225T-C-OY-OM-2Y-IM-OM & $2.1 \pm 0.60^{\mathrm{b}}$ & $29.2 \pm 11.90^{\mathrm{ab}}$ & $* *$ \\
\hline ICARDA-15 & CBSSOOYOO278D-G-OY-OM-2Y-OM & $2.2 \pm 1.58^{\mathrm{b}}$ & $6.5 \pm 1.57^{\mathrm{bc}}$ & $* *$ \\
\hline $1385-13$ & - & $5.3 \pm 0.99^{b}$ & $5.0 \pm 3.15^{\mathrm{bc}}$ & NS \\
\hline NGUZO & - & $17.1 \pm 15.18^{\mathrm{a}}$ & $53.1 \pm 16.71^{\mathrm{a}}$ & $* *$ \\
\hline $1512-5$ & - & $3.2 \pm 0.88^{\mathrm{b}}$ & $16.2 \pm 5.79^{\mathrm{abc}}$ & $* *$ \\
\hline KARNE & - & $5.1 \pm 2.64^{b}$ & $7.9 \pm 5.73^{\mathrm{abc}}$ & NS \\
\hline SABINI & - & $8.0 \pm 2.54^{\mathrm{ab}}$ & $16.1 \pm 5.98^{\mathrm{abc}}$ & $* *$ \\
\hline
\end{tabular}

TABLE 8: Effect of stem rust Ug99 on gluten content (\%) of barley.

\begin{tabular}{|c|c|c|c|c|}
\hline Genotypes code/name & Selection history & $\begin{array}{c}\text { Season } 1 \\
\text { Mean \%loss }\end{array}$ & $\begin{array}{c}\text { Season } 2 \\
\text { Mean \%loss }\end{array}$ & Season difference \\
\hline ICARDA-01 & CBSS99MOO39IT-H-IM-IY-IM-IY-OM & $2.4 \pm 0.90^{\mathrm{bc}}$ & $3.7 \pm 1.39^{b}$ & $* *$ \\
\hline ICARDA-02 & CBSS99MOO317T-AH-2M-IY-IM-IY-OM & $8.7 \pm 5.05^{\mathrm{ab}}$ & $5.2 \pm 2.14^{\mathrm{b}}$ & NS \\
\hline ICARDA-03 & CBSS00YOO113T-A-OY-OM-2Y-OM & $5.4 \pm 0.58^{\mathrm{abc}}$ & $3.0 \pm 0.94^{\mathrm{b}}$ & $* *$ \\
\hline ICARDA-04 & CBSS99MOO429T-L-IM-IY-OM & $5.7 \pm 1.86^{\mathrm{abc}}$ & $8.9 \pm 2.80^{\mathrm{ab}}$ & $* *$ \\
\hline ICARDA-05 & CBSW99WMOOO95T-B-IM-IY-IM-OM & $3.4 \pm 1.34^{\mathrm{bc}}$ & $2.2 \pm 0.33^{\mathrm{b}}$ & NS \\
\hline ICARDA-06 & CBSS00YOOO48S-OY-OM-2Y-OM & $5.8 \pm 0.40^{\mathrm{abc}}$ & $2.2 \pm 1.24^{\mathrm{b}}$ & $* *$ \\
\hline ICARDA-07 & CBSSOOYOO475T-O-OY-OM-2Y-OM & $4.3 \pm 1.29^{\mathrm{abc}}$ & $1.8 \pm 3.97^{\mathrm{b}}$ & NS \\
\hline ICARDA-08 & CBSSOOYOO236T-E-0Y-OM-2Y-OM & $4.8 \pm 1.70^{\mathrm{abc}}$ & $4.5 \pm 1.31^{\mathrm{b}}$ & NS \\
\hline ICARDA-09 & CBSS99MOO349T-F-3M-IY-IM-OM & $1.4 \pm 0.76^{\mathrm{c}}$ & $4.0 \pm 1.90^{\mathrm{b}}$ & $* *$ \\
\hline ICARDA-10 & CBSS99MOO468T-H-IM-IY-OM & $5.5 \pm 1.31^{\mathrm{abc}}$ & $5.6 \pm 2.33^{\mathrm{b}}$ & NS \\
\hline ICARDA-11 & CBSSOOYOO479T-D-OY-OM-IM-OM & $3.2 \pm 1.14^{\mathrm{abc}}$ & $4.6 \pm 1.91^{\mathrm{b}}$ & NS \\
\hline ICARDA-12 & CBSW98WOOO54S-BY-2M-IY-2M-IY-OM & $3.5 \pm 1.58^{\mathrm{abc}}$ & $3.8 \pm 1.80^{\mathrm{b}}$ & NS \\
\hline ICARDA-13 & CBSS99MOO315T-F-IM-F-IM-IY-IM-IY-OM & $1.5 \pm 0.42^{\mathrm{c}}$ & $3.2 \pm 1.70^{\mathrm{b}}$ & NS \\
\hline ICARDA-14 & CBSSOOYOO225T-C-OY-OM-2Y-IM-OM & $2.0 \pm 0.73^{c}$ & $6.5 \pm 3.45^{\mathrm{b}}$ & NS \\
\hline ICARDA-15 & CBSSOOYOO278D-G-OY-OM-2Y-OM & $1.2 \pm 0.51^{\mathrm{c}}$ & $2.0 \pm 1.14^{\mathrm{b}}$ & NS \\
\hline $1385-13$ & - & $3.8 \pm 0.90^{\mathrm{abc}}$ & $5.3 \pm 0.51^{\mathrm{b}}$ & $* *$ \\
\hline NGUZO & - & $9.8 \pm 7.17^{\mathrm{a}}$ & $3.6 \pm 2.25^{\mathrm{b}}$ & NS \\
\hline $1512-5$ & - & $4.0 \pm 0.97^{\mathrm{abc}}$ & $5.4 \pm 2.73^{\mathrm{b}}$ & NS \\
\hline KARNE & - & $0.8 \pm 1.45^{c}$ & $5.0 \pm 3.69^{b}$ & NS \\
\hline SABINI & - & $8.1 \pm 2.62^{\mathrm{ab}}$ & $16.3 \pm 7.7^{\mathrm{a}}$ & NS \\
\hline
\end{tabular}

* Any two means in a column whose S.E. values overlap are not different at $\alpha=0.05$ by DMRT. ${ }^{*}$ Means followed by the same letter in column are not significantly different at $(P \leq 0.05)$.

**NS means the genotype was significantly and not significantly different between season. 
the quality of barley which is an important factor for malting. It causes losses in germination, starch, and protein aspects of barley. By reducing the quality it is evident that the stem rust Ug99 is a threat to beer industry in the country and in the whole world. This emphasizes the need for regular monitoring of the stem rust pathogen, in particular isolates in the variable Ug99 lineage, as well as continued resistance breeding. The information in this study is beneficial to both researchers, barley and wheat producers in confronting a pathogen that is devastating with feasible chemical control though expensive and unfriendly to the environment.

\section{Acknowledgments}

Funding from the Graduate School of Egerton University is gratefully acknowledged. The assistance of Dr. Gethi, Macharia G. K., and Mr. Kamundia from the National Plant Breeding Centre Njoro and Mr. Sylvester Denda from East Africa Malting for providing Kenyan genotypes used in this study is also appreciated.

\section{References}

[1] African Breweries East, The Kenyan Beer Industry, Nairobi, Kenya, 2005.

[2] J. Chełkowski, M. Tyrka, and A. Sobkiewicz, "Resistance genes in barley (Hordeum vulgare L.) and their identification with molecular markers," Journal of Applied Genetics, vol. 44, no. 3, pp. 291-309, 2003.

[3] K. J. Williams, "The molecular genetics of disease resistance in barley," Australia Journal of Agriculture Research, vol. 54, pp. 1065-1079, 2003.

[4] M. S. Hovmøller and A. F. Justesen, "Rates of evolution of avirulence phenotypes and DNA markers in a northwest European population of Puccinia striiformis f. sp. tritici," Molecular Ecology, vol. 16, no. 21, pp. 4637-4647, 2007.

[5] CIMMYT, Sounding the Alarm on Global Stem Rust. An Assessment of Ug99 in Kenya and Ethiopia and Potential for Impact in neighboring Regions and beyond, 2005.

[6] FAO, Meeting of the Technical Subgroup of the Expert Group on International Economic and Social Classifications, United Nations Department of Economic and Social Affairs Statistics Division, New York, NY, USA, 2004.

[7] Kenya Agricultural Research Institute, Effect of a New Race on Wheat Production/Use of Fungicides and Its Cost in Large vs. Small Scale Farmers, Situation of Current Cultivars, KARI, Njoro, Kenya, 2005.

[8] R. Wanyera, M. G. Kinyua, Y. Jin, and R. P. Singh, "The spread of stem rust caused by a. Puccinia graminis $\mathrm{f}$. sp. tritici, with virulence on Sr31 in wheat in Eastern Africa," Plant Disease, vol. 90, p. 113, 2006.

[9] Z. A. Pretorius, R. P. Singh, W. W. Wagoire, and T. S. Payne, "Detection of virulence to wheat stem rust resistance gene Sr31 in Puccinia graminis f. sp. tritici in uganda," Plant Disease, vol. 84, article 203, no. 2, 2000.

[10] B. J. Steffenson and Y. Jin, "Resistance to race TTKS of Puccinia graminis f. sp. tritici in barley," Phytopathology, vol. 96, p. 110, 2006.

[11] A. P. Roelfs and J. W. Martens, "An international system of nomenclature for Puccinia graminis f. sp. tritici," Phytopathology, vol. 78, pp. 526-533, 1989.
[12] R. E. Welty and R. E. Barker, "Evaluation of resistance to stem rust in perennial ryegrass grown in controlled and field condition," Plant Disease, vol. 76, pp. 637-641, 1992.

[13] R. A. McIntosh, C. R. Wellings, and R. F. Park, Wheat Rusts: An Atlas of Resistance Genes, CSIRO Publications, East Melbourne, Australia, 1995.

[14] E. C. Stakman, D. M. Stewart, and W. Q. Loegering, Identification of Physiological Races of Puccinia graminis var tritici, U.S Department of Agriculture Research Service, Washington, DC, USA, 1962.

[15] A. P. Roelfs, R. P. Singh, and E. E. Saari, Rust Diseases of Wheat: Concepts and Methods of Disease Management, CIMMYT, Mexico City, Mexico, 1992.

[16] R. Jaetzold and H. Schmidt, Farm Management Handbook of Kenya, vol. 2 of Natural Condition and Farm Management Information, Ministry of Agriculture, Nairobi, Kenya, 1983, In Cooperation with Germany Agricultural Team (GAT) of the Germany Agency for Technical Cooperation (GTZ).

[17] J. C. Zadoks, T. T. Chang, and C. F. Konazak, "A decimal code for growth stages of cereals," Weed Research, vol. 14, pp. 415421, 1974.

[18] R. F. Peterson, A. B. Campbell, and A. E. Hannah, "A diagramic scale for estimating rust intensity of leaves and stems cereals," Canadian Journal of Research, vol. 26, pp. 496-600, 1948.

[19] Y. Jin, B. J. Steffenson, and J. D. Miller, "Inheritance of resistance to pathotypes QCC and MCC of Puccinia graminis $\mathrm{f}$. sp. tritici. In barley lines Q21861 and temperature effect on the expression of resistance," Phytopathology, vol. 84, pp. 452-455, 1994.

[20] S. L. Fox and D. E. Harder, "Resistance to stem rust in selected barley lines and the inheritance of resistance to pathotype QCC," Canadian Journal of Plant Science, vol. 75, pp. 781-788, 1995.

[21] D. E. Briggs and J. L. Woods, "Dormancy in malting barley: Studies on drying, storage biochemistry and physiology," HGCA Project Report 84, 1993.

[22] R. Benech-Arnold, "Bases of pre-harvest sprouting resistance in barley: physiology, molecular biology and environment control of dormancy in the barley grain," in Barley Science: Recent Advances from Molecular Biology to Agronomy of Yield and Quality, G. A. Slafer, J. L. Molina-Cano, R. Savin, J. L. Arausi, and I. Romagos, Eds., Food Products Press, New York, NY, USA, 2000.

[23] E. Antonelli and J. M. Daly, "Decarboxylation of indolecsetic acid by near isogenic lines of wheat resistant or susceptible to Puccinia graminis f.sp. tritici," Phytopathology, vol. 56, pp. 610618, 1966.

[24] L. B. Johnson, B. L. Brannaman, and F. B. Zscheile Jr., "Protein and enzyme changes in wheat leaves following infection with Puccinia recondite," Phytopathology, vol. 58, pp. 578-583, 1968.

[25] G Gassner and W. Franke, "Untersuchungen über den Stickstoffhaushalt rostinfizierter Getreideblätter," Phytopathologische Zeitschrift, vol. 11, pp. 517-570, 1938. 


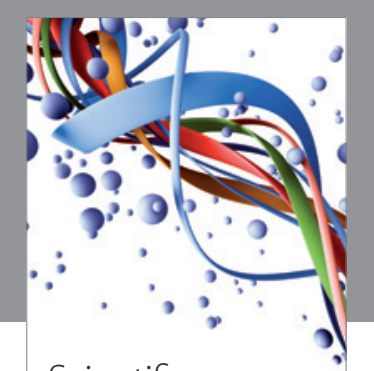

Scientifica
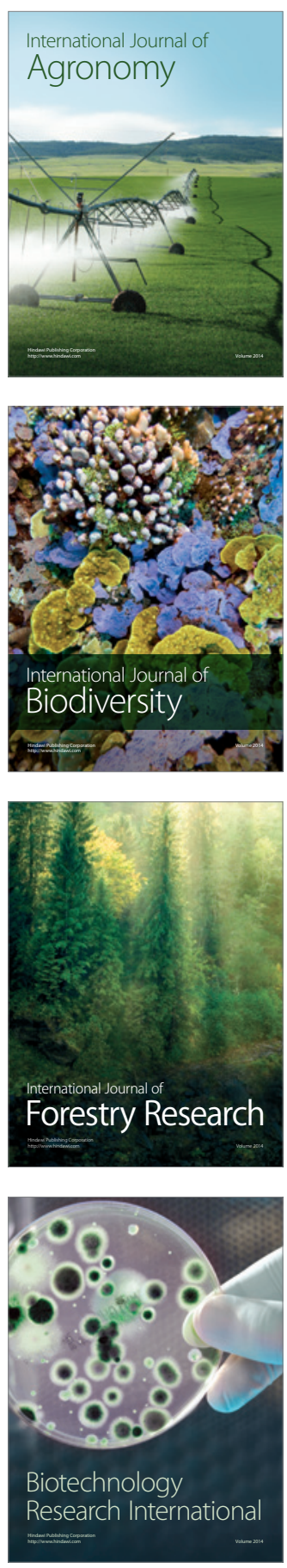
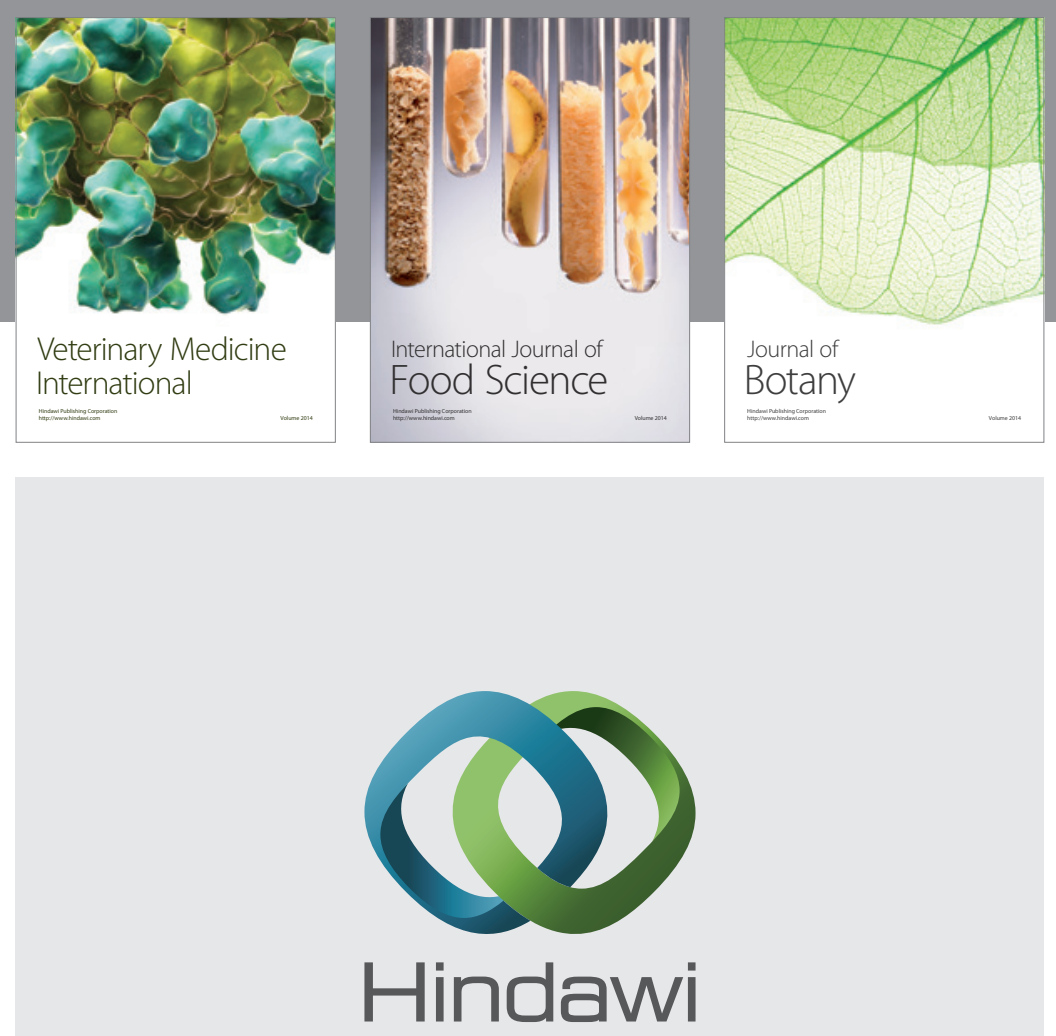

Submit your manuscripts at

http://www.hindawi.com
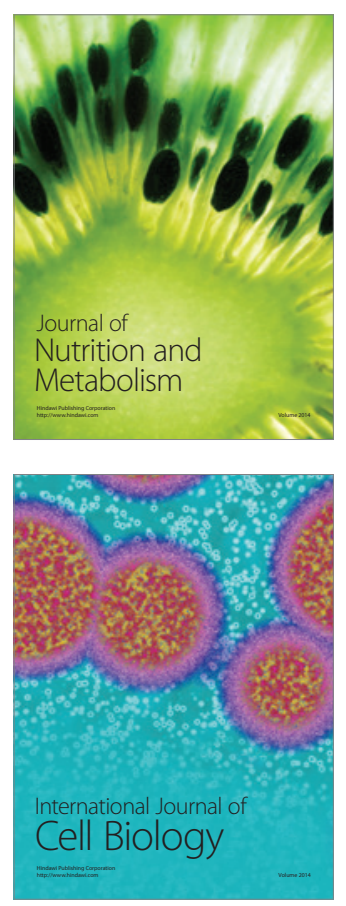
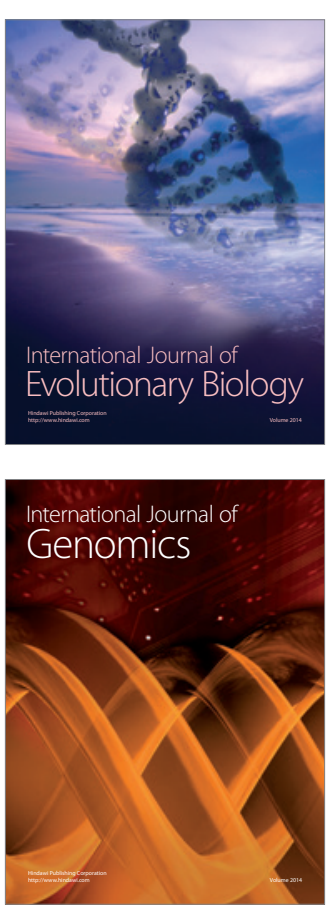
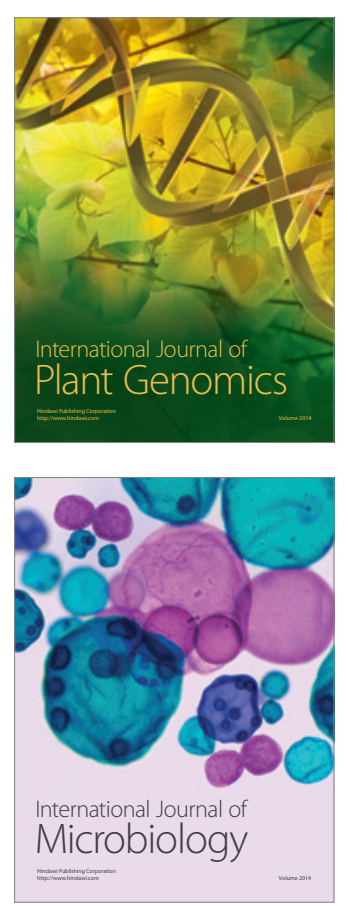

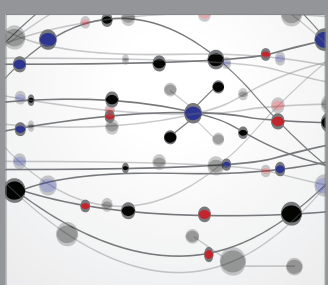

The Scientific World Journal
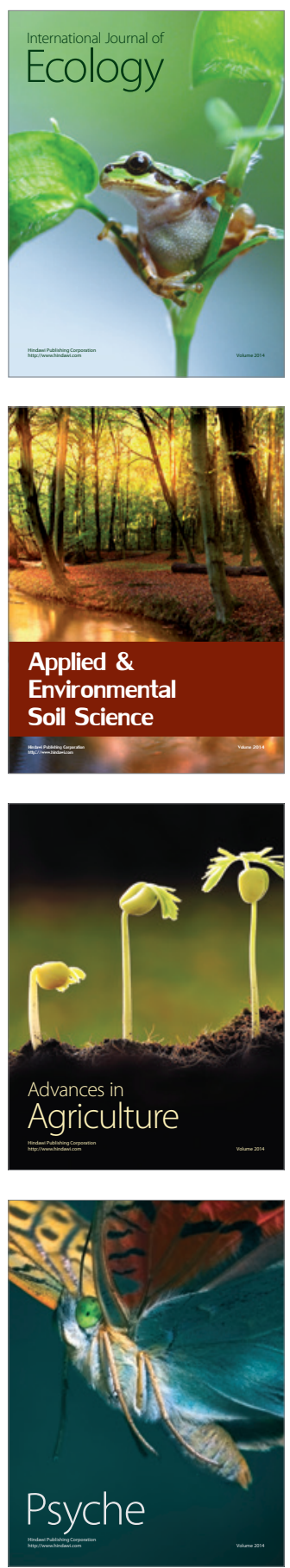